\title{
A BRIEF ANNOUNCEMENT FROM THE INTERIM HONORARY TREASURER
}

\author{
Kevin C Moore MB ChB FRCA
}

Rishworth, Yorkshire, UK

W hen many people retire, they find themselves faced with an endless series of empty days stretching far in front of them, and therefore seek small tasks to fill their time. I am one of the very lucky few for whom the opposite is the truth. Now I have actually retired from my full time post, I find that my days are fuller than ever, and so I have to seek tasks which I have, with regret, to divest myself of.

One of these is my interim task as WALT Honorary Treasurer. I had actually hoped that the divestiture would have occurred soon after the WALT Tsukuba meeting more than 2 years ago but hopes are too often fleeting things, and in this case circumstances just did not work out, very sadly so. The long and the short of it is (not so long and very short), I will no longer fill the gap, and it is time for me to pass the mantle of Treasurer on to whomsoever is proposed and elected in Brazil. I will make sure that our valiant and hardpressed Secretary-General has all the relevant books and papers, and as soon as the new Treasurer is appointed he or she will be able to transfer the funds to the new WALT bank account, wherever it may be. Of course, a large body of our funds have rested with Professor Enwemeka, but all the paperwork is available and that amount will be accounted for by him. I will not and should not go into details here: Dr Kubota will have all of the relevant details and substantiating paperwork well before the WALT 2004 meeting General Assembly, where I have asked him to present the accounts on my behalf, unless a new interim Hon. Treasurer is appointed in the meantime.

My time with ILTA, and then WALT has been at worst, interesting, and at best, most enjoyable. There is a great deal of regret in letting go, but there is also relief. Enough, as the man said, is enough! As for my successor, here is something for you all to think about. In some other associations with which I am involved, the tasks of Treasurer and Membership Secretary have devolved to the one person, since that makes a great deal of administrative sense. I am not proposing this should necessarily be the case for WALT, merely putting the thought forward so that the Executive have somewhere to start when considering how to fill the gap.

Lastly, I am happy to be writing this short note for inclusion in the second Pilot Issue of Laser Therapy. I had the honour to be the principal author of one of the two papers in the very first Pilot Issue, back in 1988, and I am further honoured that the same paper has been chosen for inclusion in this issue. A great deal of water has passed under the bridges during the intervening years, but it remains very much my firm belief that the World Association for Laser Therapy will be best served by a journal dedicated to the many facets of phototherapy and associated research, rather than a mix of photosurgery and phototherapy. I salute Dr Toshio Ohshiro for his enthusiastic support, both financial and intellectual, and I wish Profs. Trelles and Arakelyan all the very best of luck with what I am certain will be a successful venture. Unlike old soldiers, I really trust that Laser Therapy will neither die nor fade away.

Rishworth, Yorks., UK, October 2004 Kevin C Moore 